\title{
Hubungan Inisiasi Menyusu Dini (IMD) Dengan Produksi ASI Pada Ibu Menyusui Di Pustu Penen Wilayah Puskesmas Biru-Biru Kecamatan Biru- Biru Tahun 2017
}

\author{
Hanna Sriyanti Saragih ${ }^{1}$, Julietta Hutabarat ${ }^{2}$ \\ Poltekkes Kemenkes Medan ${ }^{12}$ \\ ${ }^{1}$ hannasriyanti02@gmail.com
}

\begin{abstract}
One of the SDGs achievement targets is to reduce the IMR at least to 12 per 1,000 live births. Based on the results of the study it was showed that 13\% of infant deaths can be prevented by breastfeeding because they contain antibodies that protect babies against diseases that can cause death. Mothers often have difficulty to breastfeed their babies. One of the problems causing the failure is due to not doing early breastfeeding initiation. This study is to determine the relationship of early breastfeeding initiation with the production of breast milk in breastfeeding mothers. This type of research was analytic descriptive with cross sectional design carried out in Penen assistant community health centre of Sibiru-biru community health centre in Biru-biru sub district. The population used in the study were all breastfeeding mothers in Penen assistant community health centre of Sibiru-biru community health centre in Biru-biru sub district. Samples were taken in total sampling of 42 respondents. Data collection was using questionnaires and checklist sheets. Data were analyzed in a univariate and bivariate analysis using Chi-square statistical tests by computerization. The results obtained more than half (52.4\%) of breastfeeding mothers have enough breast milk production, more than half (59.5\%) of breastfeeding mothers did early breastfeeding initiation. There was a significant relationship of early breastfeeding initiation with breast milk production in breastfeeding mothers. $(p$-value $=0.006(p<0.05))$. Based on the results of the study above, it can be concluded that the action of early breastfeeding initiation affected breast milk's production. It is expected that health workers who help delivery process always have an early breastfeeding initiation in each delivery process.
\end{abstract}

Keyword : early breastfeeding initiation; breastmilk's production

\begin{abstract}
ABSTRAK
Salah satu target capaian SDGs adalah menurunkan AKB setidaknya hingga 12 per $1.000 \mathrm{KH}$. Berdasarkan hasil penelitian 13\% kematian bayi dapat dicegah dengan pemberian ASI karena mengandung antibody yang melindungi bayi terhadap penyakit yang dapat menyebabkan kematian. Seringkali ibu mengalami kesulitan untuk menyusui bayinya. Salah satu masalah penyebab kegagalan tersebut adalah karena tidak melakukan IMD. Penelitian ini untuk mengetahui hubungan IMD dengan produksi ASI pada ibu menyusui.

Jenis penelitian ini adalah deskriptif analitik dengan desain cross sectional yang dilaksanakan di Pustu Penen Wilayah Puskesmas Biru-Biru Kecamatan Biru-Biru. Populasi yang digunakan dalam penelitian adalah semua ibu menyusui di wilayah Pustu Penen Kecamatan Biru-Biru. Sampel diambil secara total sampling sebanyak 42 responden. Pengumpulan data menggunakan kuesioner dan lembar ceklist Data dinalisa secara univariat dan bivariat dengan menggunakan uji statistic Chi-square menggunakan komputerisasi.

Hasil penelitian didapat lebih dari separoh (52,4\%) ibu menyusui memiliki produksi ASI Cukup, lebih dari separoh (59,5\%) ibu menyusui dilakukan IMD. Ada hubungan bermakna IMD dengan produksi ASI pada ibu menyusui . $(\mathrm{p}$-value $=0,006(\mathrm{p}<0,05))$.

Berdasarkan hasil penelitian diatas dapat disimpulkan tindakan IMD mempengaruhi produksi ASI. Diharapkan kepada petugas kesehatan yang membantu proses persalinan untuk selalu melakukan IMD pada setiap persalinan.
\end{abstract}

Kata kunci : IMD, Produksi ASI 


\section{PENDAHULUAN}

\section{Latar Belakang}

Tujuan ketiga dari Sustainable Development Goals (SDGs) adalah menjamin kehidupan yang sehat dan mendorong kesejahteraan bagi semua orang di segala usia dimana salah satu target capaiannya adalah menurunkan Angka Kematian Bayi (AKB) setidaknya hingga 12 per 1.000 Kelahiran Hidup (KH) dan Angka Kematian Balita (AKBa) 25 per $1.000 \mathrm{KH}$ pada tahun 2030 . Menurut penelitian Jones (2003) dan Edmond (2006) dalam Roesli (2008), 13\% kematian bayi dapat dicegah dengan pemberian Air Susu Ibu (ASI), 8,8\% dengan inisiasi menyusu dini (IMD), $\quad 7,5 \%$ dengan insecixide-treated materials, 6\% dengan pemberian makanan pendamping ASI dan $5 \%$ dengan pemberian Zinc.

Menurut Roesli, ${ }^{12}$ upaya pemberian ASI dengan membiarkan bayi merangkak di atas perut Ibu dan mencari puting susu sendiri segera setelah proses kelahiran dikenal dengan Inisiasi Menyusu Dini (IMD). Istilah IMD sebenarnya sudah ada sejak tahun 1990-an. Pada tahun 1990 Dr. Lennart Righard dan seorang bidan Margareta Alade melakukan penelitian yang melibatkan 72 pasangan ibubayi baru lahir. Hasil penelitian menunjukkan bahwa dengan menunda permulaan menyusu lebih dari satu jam dapat mneyebabkan kesukaran menyusu pada bayi. Pada tahun 1978, Sose dkk CIBA Foundation juga melakukan penelitian dengan hasil bahwa bayi yang diberi kesempatan menyusu dini dengan cara kontak kulit ibu-kulit bayi setidaknya satu jam, hasilnya bayi-bayi tersebut lebih lama disusui. Tahun 2003 Fika dan Syafik dalam Journal Kedokteran Trisakti menuliskan bahwa dari penelitian yang dilakukan di Jakarta menunjukkan bahwa bayi yang diberi kesempatan menyusu dini, hasilnya delapan kali lebih berhasil ASI eksklusif daripada yang tidak diberi kesempatan IMD.

IMD dalam satu jam pertama pasca lahir menurunkan $22 \%$ resiko kematian bayi usia 0-28 hari. Sebaliknya, penundaan inisiasi menyebabkan resiko kematian. Bahkan bila inisiasi menyusu terlambat dilakukan (setelah hari pertama), dapat meningkatkan resiko kematian 2-4 kali. Penelitian di RS St.Carolus tahun 2008 pada 276 bayi yang dilakukan IMD, didapatkan angka keberhasilan IMD pada kelahiran spontan sebesar $82 \%$ sedangkan dengan alat bantuan (ektraksi vakum) sebesar $44 \%$ dan pada operasi bedah Caesar 59\%. Penelitian ini juga membuktikan bahwa IMD akan membantu keberlangsungan pemberian ASI eksklusif, produksi ASI selanjutnya dan lama menyusu.

Tahap-tahap IMD 30 menit pertama bayi istirahat diperut atau dada ibunya karena segera setelah lahir, ia belum siap minum, biasanya ia akan diam selama 20-30 menit. Bayi akan mengeluarkan suara gerakan mengisap, dan memasukan tangan ke mulutnya. Gerakan tersebut merupakan upaya si bayi arah atau sumber puting berdasarkan sumber penciumannya, si bayi mulai merangkak kearah dada ibu, dan kakinya akan menekan perut ibu bergerak kearah payudara, gerakan bayi adalah menjilat-jilat kulit ibu, menhentak kepala ke dada ibu, menekan putting, menyentuh dengan tangannya, kemudian mengulum puting payudara tersebut ia melancarkan pengeluaran ASI dari payudara ibunya. $^{5}$

Sentuhan, kuluman, dan jilatan bayi pada puting akan merangsang keluarnya hormon oksitosin. Manfaaat hormon oksitosin bagi ibu dapat membuat ibu menjadi tenang dan rileks sehingga timbul timbul rasa suka cita (bahagia) dan rasa mencintai bayi, meningkatkan ambang nyeri sehingga ibu lebih kuat menahan sakit/ nyeri, dan mengkontraksikan otot-otot di sekeliling kelenjer ASI sehingga ASI dapat terpencar keluar. ${ }^{17}$

Sebagai upaya untuk tetap mempertahankan prolaktin dalam kadar darah ibu sebelum setengah jam pertama setelah persalinan, isapan bayi ini akan memberi rangsangan pada hipofisis untuk mengeluarkan hormon oksitosin. Hormon oksitosin bekerja merangsang otot polos untuk memeras ASI yang ada di aveoli, lobus, serta duktus yang berisi ASI yang dikeluarkan melalui putting susu. Keadaan ini akan memaksa hormon proklatin untuk memprodusi ASI. Dengan keluarnya ASI, prolaktin terangsang untuk segera memproduksi ASI. Semakin sering bayi menyusu, merangsang prolaktin untuk terus memproduksi ASI. ${ }^{10}$

Penelitian Susanti

menunjukkan bahwa rata-rata waktu keluarnya ASI pada ibu yang melakukan IMD adalah 
11,29 jam sedangkan pada ibu yang tidak melakukan IMD adalah 36,7 jam. $^{18}$

Presentasi pemberian ASI Eksklusif pada bayi 0-6 bulan di Indonesia tahun 2013 sebesar $54,3 \%$ sedangkan presentase proses mulai mendapat ASI kurang dari satu jam pada bayi umur $0-23$ bulan sebesar 34,5\%. ${ }^{4}$

Seringkali ibu mengalami kesulitan untuk menyusui bayinya, salah satunya adalah dikarenakan kegagalan atau tidak dilakukannya IMD setelah bayi lahir. ${ }^{12}$

Pustu Penen Kecamatan Biru-Biru merupakan wilayah kerja Puskesmas BiruBiru dengan cakupan pemberian ASI Eksklusif yang paling rendah yaitu $18,3 \%$. Hasil wawancara terhadap 5 orang ibu menyusui mengatakan telah memberikan bayi susu formula saat lahir dengan alasan ASI lama baru keluar dan tidak lancar sehingga bayi menjadi rewel. Ketiga ditanyakan tentang pelaksanaan IMD pada saat proses persalinan, 4 dari 5 ibu menyusui mengatakan tidak bersedia melakukan IMD dengan alasan ibu lelah dan bayi masih kotor.

Untuk itu Inisiasi menyusu dini dapat memberikan kesempatan pada bayi untuk mulai menyusu segera setelah bayi dilahirkan. Maka perlu dipastikan bahwa bayi mendapatkan kesempatan untuk melakukan proses inisiasi menyusui paling tidak satu jam pertama setelah ia lahir. Hal ini akan menunjang proses lancarnya ASI di kemudian hari. Berdasarkan latar belakang di atas penulis tertarik untuk melakukan penelitian dengan judul "Hubungan Inisiasi Menyusu Dini dengan produksi ASI pada ibu menyusui Di Pustu Penen Wilayah Puskesmas Biru-Biru Kecamatan Biru-Biru Tahun 2017”

\section{Tujuan penelitian}

Untuk mengetahui Hubungan Inisiasi Menyusu Dini Dengan Produksi ASI pada Ibu Menyusui Di Pustu Penen Wilayah Puskesmas Biru-Biru Kecamatan Biru-Biru Tahun 2017, yaitu dengan melihat distribusi frekuensi Produksi Air Susu Ibu, frekuensi Inisiasi Menyusu Dini Pada Ibu Menyusui Di Pustu Penen Wilayah Kerja Puskesmas Biru-Biru dan hubungan inisiasi menyusu dini dengan produksi air susu ibu pada ibu menyusui di Pustu Penen wilayah kerja Biru-Biru.

\section{Manfaat penelitian}

Data atau informasi hasil penelitian ini dapat menjadi masukan bagi Puskesmas Biru-Biru dalam mengambil kebijakan lebih lanjut untuk meningkatkan pelaksanaan IMD yang berkontribusi dalam meningkatkan cakupan pemberian ASI Eksklusif dan dapat dimanfaatkan petugas Puskesmas Biru-Biru terutama petugas penyuluhan dalam meningkatkan pelaksanaan IMD dalam proses persalinan normal.

\section{METODE PENELITIAN}

Penelitian ini merupakan penelitian deskriptik analitik yaitu menggambarkan hubungan antara variabel independent dengan variabel dependent, dengan pendekatan yang digunakan adalah cross sectional yaitu pendekatan yang menekankan pada waktu pengukuran data variabel independent (IMD) dan variabel dependent (Produksi Air Susu Ibu) yang diteliti secara bersamaan (Nursalam,2011), yang telah dilakukan di Pustu Penen wilayah Puskesmas Biru-Biru Kecamatan Biru-Biru dengan alasan merupakan salah satu wilayah dengan cakupan ASI Eksklusif yang paling rendah dan peneliti bekerja di lokasi penelitian sehingga memudahkan peneliti dalam melakukan penelitian pada bulan Desember 2016 - Juni 2017 mulai dari penelusuran kepustakaan, pembuatan proposal, pengumpulan data, penulisan laporan penelitian dan sidang hasil penelitian.

Populasi pada penelitian ini adalah seluruh ibu menyusui yang memiliki bayi $0-1$ bulan saat penelitian di Pustu Penen wilayah Puskesmas Biru-Biru Kecamatan Biru-Biru yang berjumlah 42 orang yang terdistribusi di Desa Peria-ria 19 orang, Desa Penen 15 orang dan Desa Mardinding 8 orang, dengan sampel 42 orang sehingga seluruhnya diambil menjadi sampel penelitian (Total Populasi).

Jenis data yang digunakan dalam penelitian diperoleh melalui wawancara dengan mengggunakan kuesioner tentang pelaksanaan IMD dan produksi ASI yang dibuat oleh peneliti berdasarkan konsep teoritis dengan terlebih dahulu memberikan penjelasan singkat tentang tujuan penelitian serta cara pengisian kuesioner, sedangkan data 
Vol. 15 No. 1 Januari - April 2020

sekunder adalah data ibu yang memiliki bayi usia 0-1 bulan saat dilakukan penelitian yang diperoleh dari pendokumentasian Pustu Penen.

Data yang diperoleh adalah data primer yang diperoleh langsung oleh peneliti dari pengumpulan data mengenai Hubungan

\begin{tabular}{c|c|c|c}
\hline No & IMD & $\begin{array}{c}\text { Frekuensi } \\
\text { (f) }\end{array}$ & $\begin{array}{c}\text { Presentase } \\
\text { (\%) }\end{array}$ \\
\hline 1 & $\begin{array}{c}\text { Tidak } \\
\text { dilakukan }\end{array}$ & 17 & 40,5 \\
2 & Dilakukan & 25 & 59,5 \\
\hline & Jumlah & 42 & 100,0 \\
\hline
\end{tabular}

Inisiasi Menyusu Dini dengan Produksi Air Susu Ibu Pada Ibu Menyusui Di Pustu Penen Wilayah Kerja Puskesmas Biru-Biru Tahun 2017, dengan cara melihat hasil kuesioner dan lembar checklist yang berisi pertanyaan atau pernyataan tentang ada atau tidaknya Hubungan Inisiasi Menyusui Dini Terhadap Produksi Air Susu Ibu . Data diolah dengan proses editing, coding, entry dan cleaning. Seterusnya data dianalisis secara univariat dan bivariate.

\section{HASIL PENELITIAN DAN PEMBAHASAN}

\section{Hasil Penelitian}

Berdasarkan hasil pengumpulan data pada penelitian dengan judul tentang "Hubungan Inisiasi Menyusu Dini dengan Produksi ASI Pada Ibu Menyusui di Pustu Penen wilayah Puskesmas Biru-Biru Kecamatan Biru-Biru Tahun 2017" dengan jumlah responden 42 orang didapatkan :

Tabel 4.1

\section{Distribusi Produksi ASI Pada Ibu Menyusui Di Pustu Penen} wilayah Puskesmas Biru-Biru Kecamatan Biru-Biru Tahun 2017

\begin{tabular}{c|c|c|c}
\hline $\begin{array}{c}\mathrm{N} \\
\mathrm{o}\end{array}$ & $\begin{array}{c}\text { Produks } \\
\text { i ASI }\end{array}$ & $\begin{array}{c}\text { Frekuens } \\
\text { i (f) }\end{array}$ & $\begin{array}{c}\text { Presentas } \\
\text { e (\%) }\end{array}$ \\
\hline 1 & Cukup & 22 & 52,4 \\
\hline
\end{tabular}

\begin{tabular}{c|c|c|c}
\hline 2 & Kurang & 20 & 47,6 \\
\hline & Jumlah & 42 & 100,0 \\
\hline
\end{tabular}

Berdasarkan dari hasil tabel 4.1 dapat terlihat bahwa dari 42 ibu menyusui lebih dari separoh $(52,4 \%)$ memiliki produksi ASI kategori cukup.

\section{Tabel 4.2}

Distribusi IMD Pada Ibu Menyusui Di Pustu Penen Wilayah Puskesmas Biru-Biru Kecamatan Biru-Biru Tahun 2017

Berdasarkan dari hasil tabel 4.2 dapat terlihat bahwa dari 42 ibu menyusui lebih dari separoh $(59,5 \%)$ ibu menyusui melakukan IMD.

\section{Tabel 4.3}

Hubungan IMD Dengan Produksi ASI Pada Ibu Menyusui Di Pustu Penen Wilayah Puskesmas BiruBiru Kecamatan Biru-Biru Tahun 2017

\begin{tabular}{|c|c|c|c|c|c|c|}
\hline \multirow{2}{*}{ IMD } & \multicolumn{3}{|c|}{ Produksi ASI } & \multicolumn{2}{|c|}{\begin{tabular}{c}
\multirow{2}{*}{ Kuran } \\
g
\end{tabular}} & \multicolumn{2}{|c|}{ Cukup } & \multicolumn{2}{c}{ Total } \\
\cline { 2 - 6 } & $\mathrm{f}$ & $\%$ & $\mathrm{f}$ & $\%$ & $\mathrm{f}$ & $\%$ \\
\hline Tidak & & 7 & & 23, & & 1 \\
dilakuk & 13 & 6, & 4 & 5 & 17 & 0 \\
an & & 5 & & & & 0 \\
\hline Dilakuk & & 2 & & 72, & & 1 \\
an & 7 & 8, & 18 & 0 & 25 & 0 \\
& & 0 & & & & 0 \\
\hline \multirow{2}{*}{ Jumlah } & 2 & 4 & & 52, & & 1 \\
& 0 & 7, & 22 & 4 & 42 & 0 \\
& & 6 & & 4 & & 0 \\
\hline
\end{tabular}

Berdasarkan dari hasil 149able 4.3 dapat terlihat dari 17 orang ibu menyusui yang tidak dilakukan IMD, 13 orang $(76,5 \%)$ memiliki produksi ASI kategori kurang, sedangkan 25 ibu menyusui yang dilakukan IMD sebanyak 18 orang (72,0\%) dengan produksi kategori cukup. Berdasarkan hasil Uji Statistik person Chi 
Square didapatkan p-value $=0,006(\mathrm{p}<$ $0,05)$ artinya $\mathrm{H}_{0}$ ditolak, sehingga dapat disimpulkan ada hubungan antara Inisiasi Menyusu Dini dengan Produksi Air Susu Ibu Pada Ibu Menyusui di Pustu Penen Wilayah Puskesmas Biru-Biru Kecamatan Biru-Biru tahun 2017.

\section{Pembahasan}

Terlihat bahwa dari lebih dari setengah ibu menyusui memiliki produksi ASI kategori cukup. Produksi ASI cukup dapat diketahui berdasarkan bagaimana responden menjawab pertanyaan yang diberikan. Hasil penelitian ini sesuai dengan teori Saleha ${ }^{13}$, dimana untuk mengetahui banyaknya produksi ASI seseorang adalah dilihat dari beberapa hal yaitu ASI merembes keluar melalui puting, sebelum bayi disusukan payudara terasa tegang, setelah disusui bayi akan tertidur / tenang selama kurang lebih 3-4 jam dan bayi lebih akan berkemih sekitar 8 kali sehari. Menurut analisa peneliti, produksi ASI ibu menyusui pada penelitian ini sebahagian besar pada kategori cukup karena faktor dari isapan bayi, apabila bayi lebih sering menyusui maka produksi ASI akan lebih banyak. Kosongnya simpanan ASI mengakibatkan semakin besar produksinya untuk mengisi kembali. Produksi ASI juga sangat dipengaruhi oleh makanan yang dimakan ibu, apabila ibu makan secara teratur dan cukup mengandung gizi yang diperlukan akan mempengaruhi produksi ASI, Karena kelenjar pembuat ASI tidak dapat bekerja dengan sempurna tanpa makanan yang cukup. Untuk membentuk produksi ASI yang baik, makanan ibu harus memenuhi jumlah kalori, protein, lemak, dan vitamin serta mineral. ${ }^{2}$

Lebih dari setengah ibu menyusui melakukan IMD setelah bayi lahir. Menurut Khasanah $^{5}$ IMD adalah permulaan yang awal sekali dimana bayi yang baru keluar dari rahim ibunya dibiarkan merangkak di dada sang ibu dengan susah payah untuk mencari air susu dari puting ibu. Menurut Mitayani (2010), IMD disebut juga sebagai sebagai proses Breast Crawl merupakan kontak kulit ibu dan bayi segera setelah lahir selama paling sedikit satu jam. Dalam tindakan IMD ini bayi menggunakan naluri alamiahnya untuk melakukan reflek menghisapnya dan ibu tahu bayinya siap untuk menyusui. Menurut analisa peneliti salah satu faktor yang mempengaruhi terlaksananya IMD adalah peran dari bidan sebagai tenaga kesehatan, yang membantu proses persalinan. Bidan harus senantiasa meningkatkan pengetahuannya baik melalui pendidikan non formal melalui pelatihan atau mengikuti seminar-seminar, maupun dengan meningkatkan jenjang pendidikan formal.

Berdasarkan hasil Uji Statistik Chi Square disimpulkan ada hubungan antara Inisiasi Menyusu Dini dengan Produksi Air Susu Ibu Pada Ibu Menyusui di Pustu Penen Wilayah Puskesmas Biru-Biru Kecamatan Biru-Biru tahun 2017. Hasil penelitian ini hampir sama dengan penelitian yang sebelumnya dilakukan oleh Dwi Rukma Santi ${ }^{3}$ di Bidan Praktek Swasta Firda Tuban dimana setelah di dilakukan analisa data dengan menggunakan Uji spearman terdapat hubungan yang signifikan antara IMD dengan kecepatan keluarnya ASI pada ibu post partum.Dari hasil penelitian tersebut ditemukan data bahwa IMD yang dilakukan secara tepat pada ibu post partum maka kecepatan keluarnya ASI adalah normal.

Hal ini sesuai dengan teori bahwa pembentukan ASI dapat dipercepat dengan cara menetekkan langsung bayi yang baru lahir bahkan sebelum pemotongan tali pusat. Pada 15, 30 dan 45 menit setelah bayi lahir peningkatan oksitosin yang signifikan terjadi jika bayi diletakkan kulit kekulit. Jika bayi tidak menyusu kadar oksitosin kembali kenilai dasar. Perangasangan sesegera mungkin pada payudara melalui IMD bertujuan agar kegiatan produksi dan pengeluaran ASI berjalan mulus, bayi pun dilatih 
menggunakan reflex menghisapnya sesegera mungkin agar dapat menyusu dengan benar. Disamping itu, keuntungan lain yang didapatkan dari IMD yaitu merangsang kontraksi otot rahim sehingga dapat mengurangi resiko perdarahan pasca persalinan, mengurai stress ibu setelah melahirkan, mempertahankan suhu bayi tetap hangat dan membantu perkembangan persyarafan bayi. ${ }^{13}$ Dari hasil penelitian tersebut jelas bahwa manfaat dari inisiasi menyusu dini dapat meningkatkan produksi prolaktin dan oksitosin yang dapat merangsang kolostrum segera keluar.

Pada penelitian ini juga masih ditemukan sebagian responden yang dilakukan IMD dengan produksi ASI kategori kurang. Hal tersebut menunjukkan bahwa masih banyak faktor yang dapat mempengaruhi pengeluaran ASI. diantaranya adalah faktor psikologis ibu seperti perasaan takut, malu atau nyeri hebat saat proses persalinan akan mempengaruhi refleks oksitosin yang akhirnya menekan pengeluaran ASI. Sebaliknya perasaan ibu yang bahagia, senang, perasaan menyayangi bayi, memeluk, mencium dan mendengarkan bayinya menangis atau perasaan bangga, akan meningkatkan pengeluaran ASI. Demikian juga ibu yang sudah melakukan perawatan payudara sebelum melahirkan, dimana perawatan payudara dapat melancarkan sirkulasi darah dan mencegah tersumbatnya saluran susu sehingga memperlancar pengeluaran ASI. ${ }^{14}$

\section{KESIMPULAN DAN SARAN}

Berdasarkan hasil penelitian tentang tentang hubungan Inisiasi Menyusu Dini Dengan Produksi ASI pada Ibu Menyusui di Pustu Penen Wilayah Puskesmas Biru-Biru Kecamatan Biru-Biru Tahun 2017 terlihat bahwa kurang dari setengah ibu menyusui memliki produksi ASI yang kurang dan tidak melakukan IMD setelah bayi lahir. Oleh karena itu terdapat hubungan bermakna antara IMD dengan produksi ASI pada ibu menyusui. Sehingga peneliti memberi saran agar petugas kesehatan yang membantu persalinan untuk untuk selalu melakukan IMD pada setiap proses persalinan, karena telah dibuktikan bahwa dengan dilakukannya IMD akan mempengaruhi produksi ASI selanjutnya. Hasil penelitian ini dapat digunakan untuk menambah pengetahuan dan wawasan bagi para ibu maupun tim kesehatan lain tentang IMD dan cara pelaksanaannya dan manfaatnya. Hasil penelitian ini diharapkan dapat dijadikan sebagai sumber data atau informasi bagi pengembangan penelitian kebidanan berikutnya terutama yang berhubungan dengan Inisiasi Menyusu Dini dan produksi ASI dan dapat meneliti tentang faktor lain yang mempengaruhi produksi ASI dan yang mempengaruhi pelaksanaan IMD.

\section{DAFTAR PUSTAKA}

1. Arikunto. 2011. Prosedur Penelitian Suatu Pendekatan Praktek. Jakarta : PT. Rineka Cipta

2. Arini H.2012. Mengapa Seorang Ibu Harus Menyusui. Jogjakarta: Flashbooks

3. Dwi Rukma Santi. 2009. Hubungan Inisiasi Menyusu Dini (IMD) dengan dengan kecepatan keluarnya ASI pada ibu post partum di Bidan Praktek Swasta Firda Tuban Tahun 2009.

4. Kemenkes RI, 2016. Profil Kesehatan Indonesia Tahun 2015. Jakarta. Kementerian Kesehatan Republik Indonesia

5. Khasanah, Nur. 2011. Panduan Lengkap Seputar Asi Dan Susu Formula.Jogjakarta: Flashbooks

6. Kristiyanasari, Weni. 2009. ASI Menyusui \& Sadari.Jogjakarta: Nuha Medika 
7. Mitayani. 2010. Mengenal Bayi Baru Lahir Dan Penatalaksanaan. Padang: Baduose Media

8. Notoatmodjo, 2015, Metodologi Penenitian Kesehatan. Jakarta: Rineka Cipta

9. Nursalam. 2011. Konsep dan Penerapan Metodologi Penelitian Ilmu Keperawatan. Jakarta : Salemba Medika

10. Purwanti Hubertin Sri. 2004. Konsep Penerapan Asi Eksklusif Buku Saku Bidan. Jakarta: Buku Kedoteran EGC

11. Rodiah, 2012. Faktor-Faktor Yang Berhubungan Dengan Pelaksanaan Inisiasi Menyusui Dini (IMD) Di Bidan Praktek Swasta (BPS) Kota Padang Tahun 2012. Skipsi Tidak Diterbitkan.Padang : STIKes MERCUBAKTIJAYA PADANG.

12. Roesli, U. 2008. Inisiasi Menyusu Dini Plus ASI Eksklusif. Cetakan I. Jakarta : Pustaka Bunda.

13. Saleha, Siti. 2009. Asuhan Kebidanan Pada Masa Nifas. Jakarta: Salemba Medika

14. Sulistyoningsih, Hariyani. 2011. Gizi Untuk Kesehatan Ibu Dan Anak. Yogyakarta: Graham Ilmu

15. Sulistyawati, Ari, 2009. Buku Ajar Kebidanan Pada Ibu Nifas. Yogyakarta: C.V Andi Offsset

16. Wulant, Dwitya. Inisiasi Menyusui Dini Terhadap Kelancaran Asi. hhttp://www.bloger.com.diakses tanggal 17 januari 2013

17. Yohmi, Elizabeth. 2010. Indonesia Menyusui.Jakarta: Badan Penerbit IDAI

18. Yuliarti, Nurheti. 2010. Keajaiban Asi Makanan Terbaik Untuk Kesehatan, Kecerdasan, Dan Kelincahan Si Kecil. Jakarta: C.V Andi Offset. 